\title{
PERLAKUAN KALSIUM HIDROKSIDA DAN UREA UNTUK MENINGKATKAN KUALITAS BAGAS TEBU
}

\author{
CALCIUM HYDROXYDE AND UREA TREATMENT ON THE QUALITY OF SUGARCANE \\ BAGASSE
}

\author{
Dewi Puspita Candrasari*, Subur Priyono Sasmito Budhi, dan Hari Hartadi \\ Fakultas Peternakan, Universitas Gadjah Mada, Jl. Fauna No. 3, Bulaksumur, Yogyakarta, 55281
}

\section{INTISARI}

\begin{abstract}
Penelitian bertujuan untuk konservasi hasil sisa tanaman pertanian berupa bagas tebu, meningkatkan kecernaan dan meningkatkan nilai $\mathrm{N}$ bagas tebu sehingga dapat digunakan sebagai pakan. Level $\mathrm{Ca}(\mathrm{OH})_{2}(\mathrm{~b} / \mathrm{b})$ yang digunakan sebesar 0,3 , dan $6 \%$. Level urea yang digunakan adalah 0,3 , dan 6\%. Masing-masing perlakuan diulang sebanyak 3 kali. Penelitian menggunakan rancangan acak lengkap pola faktorial 3 x 3. Setelah diberi perlakuan, bagas tebu ditempatkan pada kantong plastik polyethylene dan disimpan selama 21 hari. Data yang diperoleh dianalisis variansi dan apabila terdapat perbedaan antara perlakuan akan diuji lanjut dengan Duncan's New Multiple Range Test. Dari penelitian diperoleh hasil kandungan bahan kering (BK), bahan organik (BO), protein kasar (PK), serat kasar (SK), lemak kasar (LK), bahan ekstrak tanpa nitrogen (BETN), neutral detergent fiber (NDF), dan acid detergent fiber (ADF) masing-masing berkisar 45,06-48,51\%, 90,05-95,67\%, 1,40-4,06\%, 50,37-53,50\%, 1,33-3,33\%, 32,73-39,94\%, 80,00$90,69 \%$, dan 61,50-65,71\%. Kecernaan bahan kering (KcBK) dan kecernaan bahan organik (KcBO) bagas tebu diperoleh sebesar $24,24-39,60 \%$ dan $24,88-40,24 \%$. Disimpulkan bahwa bagas tebu yang ditambah urea $3 \%$ dan kalsium hidroksida $6 \%$ paling baik dilihat dari kandungan PK.
\end{abstract}

(Kata kunci: Bagas tebu, Kalsium hidroksida, Urea, NDF, ADF, Kecernaan in vitro)

\section{ABSTRACT}

The objectives of this experiment were to conserve the agricultural waste of sugarcane bagasse, to improve digestibility and to increase the $\mathrm{N}$ value so that sugarcane bagasse could be used as animal feed. $\mathrm{Ca}(\mathrm{OH})_{2}$ were added in DM basis of 0, 3, and 6\% (w/w). Urea level used were 40, 50, and 60\%. Each calcium hydroxide $\left(\mathrm{Ca}(\mathrm{OH})_{2}\right)$ treatments consist of 3 replications. After treatment, sugarcane bagasse were placed in polyethylene plastic bag and incubated for 21 days. Data were analyzed by Analysis of Variance $3 \times 3$ factorial arrangement and continued with Duncan's New Multiple Range Test if there were differences among treatments. Result showed the range of DM, OM, $C P, C F, E E, N F E, N D F$, and ADF of sugarcane bagasse after treatments were 45.06-48.51\%, 90.05-95.67\%, 1.40$4.06 \%, 50.37-53.50 \%, 1.33-3.33 \%, 32.73-39.94 \%, 80.00-90.69 \%$, dan $61.50-65.71 \%$, respectively. The IVDMD and IVOMD of sugarcane bagasse were $24.24-39.60 \%$ and $24.88-40.24 \%$. It could be concluded that the addition of $3 \%$ urea and $6 \%$ calcium hydroxide to sugarcane bagasse are the best based on crude protein content.

(Keywords: Sugarcane bagasse, Calcium hydroxide, Urea, $N D F, A D F$, In vitro digestibility)

\section{Pendahuluan}

Perkembangan ternak ruminansia yang pesat mengacu pada swasembada daging 2014 akan membutuhkan pakan berkualitas dalam jumlah yang banyak. Berkurangnya lahan yang digunakan untuk memproduksi hijauan mengakibatkan semakin mahalnya biaya pakan serta berkurangnya ketersediaan pakan berserat yang sifatnya konvensional. Masalah pakan menjadi salah satu kendala dalam

\footnotetext{
* Korespondensi (corresponding author):

Telp. +628 5229488428

E-mail: dewipuspita_chan@yahoo.co.id
}

mewujudkan swasembada daging tersebut. Diperlukan upaya untuk mencukupi kebutuhan pakan ruminansia dengan jalan memanfaatkan sumber pakan berserat lain yang jarang digunakan seperti pemanfaatan hasil sisa tanaman pangan.

Bagas tebu merupakan salah satu hasil sisa tanaman pangan dan merupakan limbah padat pabrik gula yang berasal dari perasan batang tebu setelah diambil niranya. Asosiasi Gula Indonesia (2010) melaporkan pada musim giling 2009, jumlah tebu yang digiling oleh 58 pabrik gula di Indonesia mencapai sekitar 34,26 juta ton, bagas tebu yang dihasilkan dari pabrik gula yaitu sebesar $34-45 \%$ 
dari berat total tebu yang digiling. Pemanfaatannya sebagai sumber pakan serat belum dapat diaplikasikan secara maksimal karena kandungan lignin yang tinggi dan berikatan kuat dengan selulosa maupun hemiselulosa membentuk ikatan lignoselulosa dan lignohemiselulosa. Gillies, (1978) menyatakan bahwa bagas tebu mengandung air $48-52 \%$, sukrosa rata-rata 3,3\%, lignin sebesar $22,09 \%$, protein kasar yang relatif rendah yaitu $2,3 \%$, dan serat kasar rata-rata $47,7 \%$. Kandungan nutrisi tersebut masih kurang dapat dimanfaatkan dengan baik oleh ternak ruminansia, jika dibandingkan dengan hijauan yang memiliki kandungan protein sekitar $7-10 \%$, serat kasar antara $31-35 \%$ (Lim, 1967).

Terdapat beberapa perlakuan untuk merenggangkan ikatan lignoselulosa bagas tebu yaitu dengan metode fisik berupa pengukusan (Zade et al., 2009), kimia dengan sodium hidroksida $(\mathrm{NaOH})$ (Suksombat, 2004), kalsium hidroksida $\left(\mathrm{Ca}(\mathrm{OH})_{2}\right)$ (Firdos et al., 1989; Pina et al., 2009), urea (Afzalani, 2004); serta biologi secara fermentasi (Albores et al., 2006).

Pertimbangan penggunaan bahan kimia kalsium hidroksida $\left(\mathrm{Ca}(\mathrm{OH})_{2}\right)$ karena banyak terdapat di alam, tidak berbahaya, dan dapat menambah nilai nutrien yaitu mineral kalsium. Penggunaan $\mathrm{Ca}(\mathrm{OH})_{2}$ juga tidak memberikan dampak yang negatif pada tanah, peternak, maupun ternaknya (Firdos et al., 1989; Fadel et al., 2003). Penelitian Firdos et al. (1989) menyebutkan bahwa penggunaan $\mathrm{Ca}(\mathrm{OH})_{2}$ sebanyak $2,5 \%$ pada pith bagasse dan disimpan selama 15 hari dapat meningkatkan kecernaan bahan kering dan bahan organik.

Upaya lain yang dapat digunakan untuk melonggarkan ikatan lignin dan meningkatkan nilai nutrien bahan pakan bagas tebu yaitu dengan menambahkan urea dengan level 3\% sampai $6 \%$ (Suksombat, 2004). Hasil penelitian Afzalani (2004) menyatakan bahwa penambahan urea 6\% pada bagas tebu amoniasi dapat menghasilkan degradasi bahan kering dan bahan organik yang lebih baik dibanding level lainnya.

Tujuan dari penelitian adalah untuk konservasi hasil sisa tanaman pertanian berupa bagas tebu, meningkatkan kecernaan, dan meningkatkan nilai $\mathrm{N}$ bagas tebu sehingga dapat digunakan sebagai pakan. Manfaat penelitian adalah untuk melihat potensi limbah hasil sisa tanaman pangan dari segi kualitas dan sebagai masukan kepada perusahaan gula untuk pengolahan dan pengawetan hasil sisa industri gula serta memberikan kemudahan dalam pembuatan pakan alternatif.

\section{Materi dan Metode}

\section{Lokasi dan waktu penelitian}

Penelitian dilaksanakan pada tanggal 25 November 2010 sampai 20 Januari 2011. Analisis proksimat dan kecernaan dilaksanakan di Laboratorium Teknologi Makanan Ternak, Fakultas Peternakan Universitas Gadjah Mada Yogyakarta. Analisis serat Van Soest dilaksanakan di Laboratorium Nutrisi dan Makanan Ternak Fakultas Peternakan Universitas Brawijaya Malang.

\section{Persiapan bagas tebu serta penambahan kalsium hidroksida $\left(\mathrm{Ca}(\mathrm{OH})_{2}\right)$ dan urea}

Penelitian dilakukan dengan menggunakan level $\mathrm{Ca}(\mathrm{OH})_{2}$ dan urea yang sama. Penambahan $\mathrm{Ca}(\mathrm{OH})_{2}(\mathrm{~b} / \mathrm{b})$ berdasarkan DM basis pada bagas tebu dengan level 0,3 , dan $6 \%$. Urea pada bagas tebu yang digunakan adalah 0,3 , dan $6 \%$. Masingmasing perlakuan diulang sebanyak 3 kali, sehingga terdapat 9 perlakuan pada penelitian ini, yaitu I (urea $0 \%+\mathrm{Ca}(\mathrm{OH})_{2} 0 \%$ ), II (urea $0 \%+$ $\mathrm{Ca}(\mathrm{OH})_{2} 3 \%$ ), III (urea $0 \%+\mathrm{Ca}(\mathrm{OH})_{2} 6 \%$ ), IV (urea $\left.3 \%+\mathrm{Ca}(\mathrm{OH})_{2} 0 \%\right), \mathrm{V}$ (urea $3 \%+\mathrm{Ca}(\mathrm{OH})_{2} 3 \%$ ), VI (urea $3 \%+\mathrm{Ca}(\mathrm{OH})_{2} 6 \%$ ), VII (urea $6 \%+\mathrm{Ca}(\mathrm{OH})_{2}$ $0 \%$ ), VIII (urea $6 \%+\mathrm{Ca}(\mathrm{OH})_{2} 3 \%$ ), dan IX (urea $\left.6 \%+\mathrm{Ca}(\mathrm{OH})_{2} 6 \%\right)$.

Bagas tebu dihomogenkan kemudian ditimbang masing-masing $1.050 \mathrm{~g}$ BK untuk masingmasing perlakuan. Selanjutnya $\mathrm{Ca}(\mathrm{OH})_{2}$ dan urea ditimbang masing-masing seberat $31,5 \mathrm{~g}$ untuk level $3 \%$ dan $63 \mathrm{~g}$ untuk level $6 \%$, lalu dilarutkan di dalam aquades. Aquades yang digunakan 50\% dari berat kering bagas tebu (Trach et al., 2001). Larutan $\mathrm{Ca}(\mathrm{OH})_{2}$ dan urea dipercikkan pada bagas tebu dan dicampur merata. Bagas tebu kemudian ditempatkan di dalam kantong plastik polyethylene kedap udara lalu disimpan selama 21 hari dan diletakkan di tempat teduh (Afzalani, 2004; Trach et al., 2001).

Bagas teramoniasi setelah proses pemeraman selama 21 hari ditimbang untuk mengetahui berat akhir selanjutnya diangin-anginkan dan kemudian dimasukkan ke dalam oven $50^{\circ} \mathrm{C}$ selama 2 hari sampai beratnya konstan, kemudian digiling menggunakan willey mill dengan diameter lubang saringan $2 \mathrm{~mm}$. Sampel tersebut kemudian digunakan untuk penetapan komposisi kimia yaitu BK, BO, PK, LK, SK, dan BETN dengan metode analisis proksimat (AOAC, 2005), komposisi serat yaitu NDF dan ADF menurut metode Van Soest, dan kecernaan in vitro menurut Tilley dan Terry (1963).

\section{Uji kecernaan in vitro}

Pengukuran kecernaan bagas tebu secara in vitro menggunakan metode 2 tahap (Tilley dan 
Terry, 1963) yang dimodifikasi Utomo (2010). Parameter kecernaan yang diamati meliputi KcBK dan $\mathrm{KcBO}$.

\section{Analisis data}

Pengaruh penambahan urea dan kalsium hidroksida pada bagas tebu diuji dengan analisis variansi dari rancangan acak lengkap pola faktorial dan dilanjutkan dengan uji Duncan's New Multiple Range Test (Steel dan Torrie, 1993).

\section{Hasil dan Pembahasan}

\section{Komposisi kimia bagas tebu}

Pada penelitian ini dilakukan pengamatan awal dan sesudah pemeraman terhadap bagas tebu yang ditambah urea dan kalsium hidroksida. Pengamatan awal didapatkan hasil analisis proksimat nilai kandungan nutrien bagas tebu tersaji pada Tabel 1, hasil pengamatan $\mathrm{pH}$ sebelum dan sesudah pemeraman tersaji pada Tabel 2 dan Tabel 3.

Penurunan $\mathrm{pH}$ hasil fermentasi dikarenakan waktu yang cukup lama digunakan oleh mikroba untuk mengubah karbohidrat yang terlarut sehingga menurunkan $\mathrm{pH}$. Penurunan $\mathrm{pH}$ ini disebabkan karena aktifitas selulolitik dari bakteri pembentuk asam laktat dimana asam laktat dapat menurunkan pH bahan (Salminen et al., 2004).

Data dalam Tabel 4 memperlihatkan adanya variasi komposisi kimia pada perlakuan yang digunakan dalam penelitian ini. Urea berpengaruh sangat nyata pada BK bagas tebu $(\mathrm{P}<0,05)$. Penurunan BK bagas tebu seiring dengan penurunan BO. Penurunan BK disebabkan adanya penguraian senyawa organik sebagai hasil aktifitas mikrobia selain itu penurunan BK disebabkan pemecahan zat yang terlarut dan mudah dicerna. Penurunan kandungan $\mathrm{BO}(\mathrm{P}<0,05)$ dapat dikarenakan aktifitas mikrobia dan penambahan kalsium hidroksida yang menyebabkan peningkatan kadar abu $(\mathrm{P}<0,05)$.

Kandungan PK meningkat $(\mathrm{P}<0,05)$ seiring dengan penambahan taraf urea. Terdapat interaksi yang nyata penambahan kalsium hidroksida dan urea terhadap kandungan protein $(\mathrm{P}<0,05)$. Taraf urea tertinggi ada pada perlakuan $\mathrm{R} 2 \mathrm{C} 3$ tapi tidak berbeda nyata dengan $\mathrm{R} 3 \mathrm{C} 1$ dan menurun seiring dengan penambahan taraf $\mathrm{Ca}(\mathrm{OH})_{2}$ namun, jika dibandingkan dengan kontrol atau bagas tebu yang tidak diberi perlakuan menunjukan kenaikan yang signifikan. Bagas tebu sebelum diolah mempunyai kadar protein sangat rendah yaitu 1,4\% (Suksombat, 2004).

Tabel 1. Komposisi kimia, serat, dan kecernaan in vitro bagas tebu kering (\% BK) (chemical composition, fiber composition and in vitro digestibility of dry sugarcane bagasse (\% DM))

\begin{tabular}{lc}
\hline \hline \multicolumn{1}{c}{ Komposisi (composition) } & Persentase (\%) (percentage (\%)) \\
\hline Bahan kering (dry matter) & 92,10 \\
Bahan organik (organic matter) & 92,55 \\
Protein kasar (crude protein) & 1,78 \\
Serat kasar (crude fiber) & 42,68 \\
Lemak kasar (extract ether) & 0,63 \\
Bahan ekstrak tanpa N (nitrogen free extract) & 47,46 \\
Neutral detergent fiber & 83,58 \\
Acid detergent fiber & 59,77 \\
Kecernaan (digestibility) & \\
$\quad$ Bahan kering (dry matter) & 21,19 \\
$\quad$ Bahan organik (organic matter) & 20,92 \\
\hline
\end{tabular}

Tabel 2. Nilai $\mathrm{pH}$ bagas tebu sebelum amoniasi ( $p H$ value of sugarcane bagasse before ammoniation)

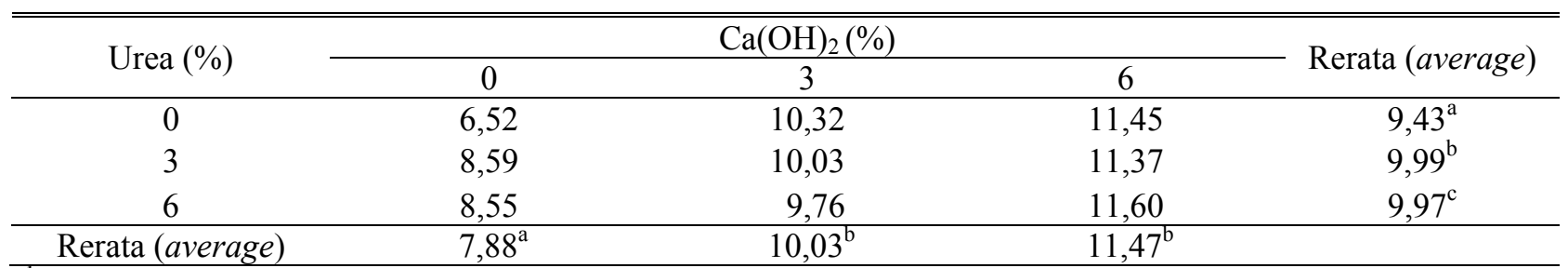

${ }^{\bar{a}, b, c}$ Superskrip yang berbeda pada baris/kolom yang sama menunjukkan perbedaan nyata $(\mathrm{P}<0,05)$ (different superscripts at the same row/column indicate significant differences $(P<0.05))$. 
Tabel 3. Nilai $\mathrm{pH}$ bagas tebu amoniasi ( $\mathrm{pH}$ value of ammoniated sugarcane bagasse)

\begin{tabular}{ccccc}
\hline \hline \multirow{2}{*}{ Urea (\%) } & \multicolumn{3}{c}{$\mathrm{Ca}(\mathrm{OH})_{2}(\%)$} & \multirow{2}{*}{ Rerata (average) } \\
\cline { 2 - 4 } & 0 & 3 & 6 & $6,54^{\mathrm{a}}$ \\
0 & 4,39 & 6,79 & 8,44 & $8,15^{\mathrm{b}}$ \\
3 & 8,12 & 8,06 & 8,28 & $8,44^{\mathrm{c}}$ \\
\hline Rerata (average) & 8,47 & 8,53 & 8,32 & \\
\hline
\end{tabular}

${ }^{a, b, c}$ Superskrip yang berbeda pada kolom yang sama menunjukkan perbedaan nyata $(\mathrm{P}<0,05)($ different superscripts at the same column indicate significant differences $(P<0.05))$.

${ }^{\mathrm{x}, \mathrm{y}, \mathrm{z}}$ Superskrip yang berbeda pada baris yang sama menunjukkan perbedaan nyata $(\mathrm{P}<0,05)($ different superscripts at the same row indicate significant differences $(P<0.05))$.

Tabel 4. Komposisi kimia bagas tebu amoniasi (\% BK) (chemical composition of ammoniated sugarcane bagasse $(\% D M))$

\begin{tabular}{|c|c|c|c|c|c|c|}
\hline Kode (code) & $\mathrm{BK}$ & $\mathrm{BO}$ & PK & LK & SK & BETN \\
\hline $\mathrm{R} 1 \mathrm{C} 1$ & $48,42 \pm 0,80$ & $95,67 \pm 0,43$ & $1,95 \pm 0,12$ & $1,75 \pm 0,21$ & $52,03 \pm 1,55$ & $39,94 \pm 1,37$ \\
\hline $\mathrm{R} 1 \mathrm{C} 2$ & $47,76 \pm 0,46$ & $93,21 \pm 0,66$ & $1,40 \pm 0,13$ & $3,33 \pm 0,36$ & $51,66 \pm 1,17$ & $36,82 \pm 1,32$ \\
\hline $\mathrm{R} 1 \mathrm{C} 3$ & $48,51 \pm 0,65$ & $90,10 \pm 1,49$ & $1,61 \pm 0,25$ & $3,22 \pm 0,90$ & $50,37 \pm 0,38$ & $34,89 \pm 2,49$ \\
\hline $\mathrm{R} 2 \mathrm{C} 1$ & $46,66 \pm 0,56$ & $95,41 \pm 0,41$ & $3,62 \pm 0,02$ & $1,33 \pm 0,22$ & $53,14 \pm 1,56$ & $37,32 \pm 1,91$ \\
\hline $\mathrm{R} 2 \mathrm{C} 2$ & $46,56 \pm 0,54$ & $92,24 \pm 0,66$ & $2,72 \pm 0,34$ & $1,54 \pm 0,32$ & $52,13 \pm 0,88$ & $35,84 \pm 0,28$ \\
\hline $\mathrm{R} 2 \mathrm{C} 3$ & $48,12 \pm 1,18$ & $90,05 \pm 0,45$ & $4,06 \pm 0,38$ & $2,52 \pm 0,42$ & $50,74 \pm 0,69$ & $32,73 \pm 0,99$ \\
\hline $\mathrm{R} 3 \mathrm{C} 1$ & $45,06 \pm 0,18$ & $95,37 \pm 0,52$ & $3,97 \pm 0,27$ & $2,05 \pm 0,16$ & $53,50 \pm 0,16$ & $35,84 \pm 0,92$ \\
\hline $\mathrm{R} 3 \mathrm{C} 2$ & $45,96 \pm 0,65$ & $92,07 \pm 1,41$ & $3,83 \pm 0,64$ & $2,01 \pm 0,32$ & $53,05 \pm 0,94$ & $33,19 \pm 1,32$ \\
\hline $\mathrm{R} 3 \mathrm{C} 3$ & $47,46 \pm 0,50$ & $90,43 \pm 0,82$ & $3,56 \pm 0,43$ & $1,84 \pm 0,72$ & $51,64 \pm 0,35$ & $33,38 \pm 0,98$ \\
\hline Rerata (average) & $47,17 \pm 0,61$ & $92,73 \pm 0,76$ & $2,97 \pm 0,29$ & $2,18 \pm 0,40$ & $52,03 \pm 0,85$ & $35,55 \pm 1,29$ \\
\hline \multicolumn{7}{|c|}{ Statistik signifikansi (statistic significancy) } \\
\hline Urea & $* *$ & ns & $* *$ & $* *$ & $*$ & $* *$ \\
\hline $\mathrm{Ca}(\mathrm{OH})_{2}$ & $* *$ & $* *$ & $* *$ & $*$ & $* *$ & $* *$ \\
\hline Urea $\mathrm{X} \mathrm{Ca}(\mathrm{OH})_{2}$ & ns & ns & $* *$ & $*$ & ns & ns \\
\hline
\end{tabular}

** high significant $(\mathrm{P}<0,01) ;{ }^{*}$ significant $(\mathrm{P}<0,05) ;$ ns: non significant $(\mathrm{P}>0,05)$

$\mathrm{R} 1$ urea $0 \%, \mathrm{R} 2$ urea $3 \%, \mathrm{R} 3$ urea $6 \%, \mathrm{C} 1: \mathrm{Ca}(\mathrm{OH})_{2} 0 \%, \mathrm{C} 2: \mathrm{Ca}(\mathrm{OH})_{2} 3 \%$, dan $\mathrm{C} 3: \mathrm{Ca}(\mathrm{OH})_{2} 6 \%$.

Perlakuan amoniasi dengan urea telah terbukti mempunyai pengaruh yang baik terhadap pakan. Proses amoniasi lebih lanjut juga akan memberikan keuntungan yaitu meningkatkan kecernaan pakan. Urea yang memiliki rumus kimia $\mathrm{CO}\left(\mathrm{NH}_{2}\right)_{2}$ dilarutkan menggunakan air akan berubah menjadi $\mathrm{NH}_{3}$ dan $\mathrm{CO}_{2} . \mathrm{NH}_{3}$ ditambah air berubah menjadi $\mathrm{NH}_{4} \mathrm{OH}$ yang akhirnya akan mengalami disosiasi menjadi $\mathrm{NH}_{4}^{+}$dan $\mathrm{OH}^{-}$dan sisanya masih bebas sebagai gas $\mathrm{NH}_{3}$ yang terdapat dalam kantong plastik tempat pemeraman karena pengaruh bakteri yang menghasilkan urease. Gas $\mathrm{NH}_{3}$ ini akan bebas keluar apabila kantong terbuka, jika akan dilakukan analisis $\mathrm{N}$ sebelum kantong dibuka.

Penuruan nilai protein seiring dengan peningkatan taraf $\mathrm{Ca}(\mathrm{OH})_{2}$ akibat dari faktor interaksi yang negatif antara urea dan $\mathrm{Ca}(\mathrm{OH})_{2}$ sesuai dengan pendapat Trach et al. (2001) yang menyatakan ketika terjadi peningkatan $\mathrm{Ca}(\mathrm{OH})_{2}$, maka urease akan menurun aktifitasnya faktor lain yang menyebabkan kadar PK menurun yaitu aktifitas bakteri yang menggunakan protein untuk kebutuhan hidupnya. Penurunan protein dapat juga dikarenakan urea yang diubah menjadi amonia dan $\mathrm{CO}_{2}$ menguap sehingga nilai $\mathrm{PK}$ menurun $(\mathrm{P}<0,05)$. Nilai protein di sini masih belum sesuai harapan karena masih di bawah PK hijauan segar. Kandungan SK bagas tebu sebelum pemeraman adalah $42,68 \%$, sesudah pemeraman berkisar $50,37 \pm 0,38 \%$ hingga $53,50 \pm 0,16 \%$ seperti yang terlihat pada Tabel 4 .

Persentase SK pada hasil analisis proksimat setelah pemeraman terlihat lebih tinggi dibandingkan SK awal dapat disebabkan oleh berkurangnya isi sel bagas yang telah dimanfaatkan bakteri untuk energi selama proses pemeraman berlangsung yang terlihat dari turunnya kandungan BETN. Kandungan lemak bagas tebu setelah amoniasi berkisar antara 1,33 $\pm 0,22$ hingga $3,33 \pm 0,36 \%$ (Tabel 4). Perlakuan urea dan kalsium hidroksida nyata menurunkan $(\mathrm{P}<0,05)$ kandungan LK bagas tebu. Turunnya persentase lemak disebabkan ber- 
kurangnya karbohidrat yang terlarut (Clayton et al., 2010). Kandungan BETN terlihat menurun $(\mathrm{P}<0,01)$ setelah diberi perlakuan urea maupun kalsium hidroksida. Hal ini disebabkan penggunaan karbohidrat sederhana yang terkandung dalam BETN oleh mikrobia. Mikrobia memanfaatkan karbohidrat tersebut untuk energi bagi pertumbuhannya.

\section{Kandungan serat Van Soest}

Hasil pengujian serat metode Van Soest (1994) tersaji pada Tabel 5. Menurut Buxton dan Redfearn (1997) karakteristik hasil sisa tanaman pertanian yaitu tingginya kandungan serat pada sisa hasil pertanian mencapai $90 \%$ dari total bahan organiknya.

Serat detergent netral (NDF) mewakili bagian dinding sel yang berserat dan terkandung di dalamnya lignin, selulosa, hemiselulosa serta beberapa protein yang terikat oleh serat. Isi sel terdiri atas zat-zat yang mudah dicerna yaitu protein, karbohidrat, mineral, dan lemak. Namun dengan perlakuan alkali yaitu penambahan $\mathrm{Ca}(\mathrm{OH})_{2}$ dan urea terhadap bagas tebu maka akan terjadi pemutusan ikatan lignoselulosa dan lignohemiselulosa. Hal ini kemungkinan yang menyebabkan penurunan nilai NDF $(\mathrm{P}<0,05)$ selain itu larutnya hemiselulosa sebagai akibat alkali yang ditambahkan dapat mengakibatkan nilai hemiselulosa juga menurun $(\mathrm{P}<0,05)$, sesuai pendapat Khan et al. (1995); Pina et al. (2009) yang menyatakan bahwa perlakuan menggunakan alkali dapat melarutkan sebagian dari hemiselulosa. Hal ini dapat dilihat bahwa semakin tinggi level urea pada proses amoniasi akan semakin banyak hemiselulosa yang terlarut, sehingga kandungan hemiselulosa pada bagas tebu semakin rendah.

Terjadi penurunan NDF dan ADF dengan semakin meningkatnya level $\mathrm{Ca}(\mathrm{OH})_{2}$, namun tidak pada penambahan urea, penurunan ADF juga tidak terlalu signifikan (Tabel 5). Hal ini dikarenakan ADF tidak merespon perlakuan alkali karena ADF mengandung komponen yang tahan terhadap perlakuan alkali. Penurunan kandungan NDF menunjukkan adanya peningkatan isi sel, penurunan $\mathrm{NDF}$ ini memperlihatkan kerja $\mathrm{Ca}(\mathrm{OH})_{2}$ yang melepaskan ikatan lignin dengan selulosa dan hemiselulosa. Hal ini sesuai dengan pernyataan Hadad et al. (1994) yang menyatakan bahwa $\mathrm{Ca}(\mathrm{OH})_{2}$ menurunkan kandungan NDF pada jerami gandum, namun kandungan ADF pada jerami gandum relatif sama pada level $\mathrm{Ca}(\mathrm{OH})_{2}$ yang berbeda. Terjadi peningkatan kandungan NDF dan ADF dari bagas tebu yang diberi perlakuan dibandingkan dengan bagas tebu tanpa perlakuan. Hal ini dapat disebabkan karena adanya penurunan karbohidrat non struktural selama proses pemeraman berlangsung (Pina et al., 2009).

\section{Kecernaan bahan kering dan bahan organik}

Pada sistem pencernaan penambahan urea dan kalsium hidroksida berpengaruh nyata terhadap KcBK $(\mathrm{P}<0,05)$ dan KcBO $(\mathrm{P}<0,05)$ yang tersaji pada Tabel 6 dan Tabel 7. Sebagai standar pada metode in vitro ini digunakan rumput pangola dan didapatkan KcBK sebesar $62,33 \%$ dan $\mathrm{KcBO}$ $61,92 \%$. Meskipun terjadi perubahan pada komposisi kimia bagas tebu setelah perlakuan, namun kecernaan yang kita lihat kurang baik karena

Tabel 5. Kandungan neutral detergent fiber (NDF) dan acid detergent fiber bagas tebu amoniasi (\% BK) (neutral detergent fiber $(N D F)$ content of ammoniated sugarcane bagasse $(\% D M)$ )

\begin{tabular}{cccc}
\hline \hline Kode $($ code $)$ & NDF & ADF & HEMISELULOSA \\
\hline R1C1 & $89,36 \pm 0,47$ & $65,71 \pm 1,10$ & $23,64 \pm 1,14$ \\
R1C2 & $86,04 \pm 0,77$ & $64,47 \pm 0,06$ & $21,58 \pm 0,83$ \\
R1C3 & $80,96 \pm 0,79$ & $61,52 \pm 1,12$ & $19,44 \pm 0,89$ \\
R2C1 & $89,49 \pm 1,26$ & $64,99 \pm 0,27$ & $24,50 \pm 1,51$ \\
R2C2 & $87,19 \pm 1,25$ & $65,12 \pm 0,89$ & $22,07 \pm 0,39$ \\
R2C3 & $82,96 \pm 2,73$ & $62,32 \pm 2,52$ & $20,65 \pm 1,58$ \\
R3C1 & $90,69 \pm 0,93$ & $65,02 \pm 1,32$ & $25,68 \pm 0,49$ \\
R3C2 & $85,61 \pm 1,46$ & $63,05 \pm 1,02$ & $22,56 \pm 2,47$ \\
R3C3 & $80,00 \pm 1,42$ & $61,50 \pm 0,68$ & $18,50 \pm 1,76$ \\
\hline Rerata $($ average $)$ & $85,81 \pm 1,23$ & $63,74 \pm 1,00$ & $22,07 \pm 1,23$ \\
\hline Urea & $\mathrm{ns}$ & $\mathrm{ns}$ & $\mathrm{ns}$ \\
$\mathrm{Ca}(\mathrm{OH})_{2}$ & $* *$ & $* *$ & $\mathrm{~ns}$ \\
Urea X Ca(OH $)_{2}$ & $\mathrm{~ns}$ & $\mathrm{~ns}$ & \\
\hline
\end{tabular}

** high significant $(\mathrm{P}<0,01)$, ns: non significant $(\mathrm{P}>0,05)$.

R1: urea $0 \%$, R2: urea 3\%, R3: urea 6\%, $\mathrm{C} 1: \mathrm{Ca}(\mathrm{OH})_{2} 0 \%, \mathrm{C} 2: \mathrm{Ca}(\mathrm{OH})_{2} 3 \%$, dan $\mathrm{C} 3: \mathrm{Ca}(\mathrm{OH})_{2} 6 \%$. 
Tabel 6. Kecernaan in vitro bahan kering bagas tebu amoniasi (\%) (in vitro dry matter digestibility of ammoniated sugarcane bagasse (\%))

\begin{tabular}{|c|c|c|c|c|}
\hline \multirow{2}{*}{ Urea $(\%)$} & \multicolumn{3}{|c|}{$\mathrm{Ca}(\mathrm{OH})_{2}(\%)$} & \multirow{2}{*}{ Rerata (average) } \\
\hline & 0 & 3 & 6 & \\
\hline 0 & $24,24 \pm 1,20$ & $25,58 \pm 1,52$ & $26,35 \pm 0,25$ & $25,39 \pm 0,99^{\mathrm{c}}$ \\
\hline 3 & $32,26 \pm 0,70$ & $32,79 \pm 1,38$ & $33,67 \pm 1,71$ & $32,91 \pm 1,26^{\mathrm{b}}$ \\
\hline 6 & $38,93 \pm 1,56$ & $39,86 \pm 0,82$ & $39,60 \pm 0,57$ & $39,46 \pm 0,98^{\mathrm{a}}$ \\
\hline Rerata (average) & $31,81 \pm 1,15^{\mathrm{b}}$ & $32,74 \pm 1,24^{\mathrm{ab}}$ & $33,22 \pm 0,84^{\mathrm{a}}$ & $32,59 \pm 1,08$ \\
\hline
\end{tabular}

Tabel 7. Kecernaan in vitro bahan organik bagas tebu amoniasi (\%) (in vitro organic matter digestibility of ammoniated sugarcane bagasse (\%))

\begin{tabular}{|c|c|c|c|c|}
\hline \multirow{2}{*}{ Urea $(\%)$} & \multicolumn{3}{|c|}{$\mathrm{Ca}(\mathrm{OH})_{2}(\%)$} & \multirow{2}{*}{ Rerata (average) } \\
\hline & 0 & 3 & 6 & \\
\hline 0 & $24,88 \pm 0,60$ & $25,36 \pm 1,22$ & $25,78 \pm 0,13$ & $25,34 \pm 0,65^{\mathrm{c}}$ \\
\hline 3 & $31,46 \pm 1,25$ & $31,29 \pm 1,34$ & $32,64 \pm 1,02$ & $31,80 \pm 1,20^{\mathrm{b}}$ \\
\hline 6 & $38,48 \pm 0,62$ & $38,36 \pm 1,52$ & $40,24 \pm 0,92$ & $39,03 \pm 1,02^{\mathrm{a}}$ \\
\hline Rerata (average) & $31,61 \pm 0,82^{b}$ & $31,67 \pm 1,36^{b}$ & $32,89 \pm 0,69^{\mathrm{a}}$ & $32,06 \pm 0,96$ \\
\hline
\end{tabular}

hasil yang masih rendah (Tabel 6 dan Tabel 7). Hal ini dapat disebabkan oleh beberapa faktor yaitu belum efektifnya level dan lama perlakuan $\mathrm{Ca}(\mathrm{OH})_{2}$, urea, maupun campuran keduanya, serta pengaruh pengeringan bagas tebu sebelum digunakan pada penelitian.

Kecernaan merupakan indikasi awal ketersediaan berbagai nutrisi yang terkandung dalam bahan pakan tertentu bagi ternak yang mengkonsumsinya. Kecernaan yang tinggi mencerminkan besarnya sumbangan nutrien tertentu pada ternak, sementara itu pakan yang mempunyai kecernaan rendah menunjukkan bahwa pakan tersebut kurang mampu mensuplai nutrien untuk hidup pokok maupun untuk tujuan produksi ternak. Rendahnya nilai kecernaan pada bagas tebu yang diamoniasi (Tabel 6) disebabkan tingginya kandungan lignin, silika, dan selulosa serta rendahnya protein sehingga enzim selulase yang dihasilkan mikrobia rumen kurang mampu bekerja. Alborés et al. (2006) juga menambahkan bahwa lignifikasi struktur polisakarida tidak hanya menghambat kecernaan polisakarida oleh mikroba rumen, tetapi juga karena adanya jaringan lignin yang tinggi membentuk hambatan fisik yang dapat mencegah kecernaan jaringan lignin terhadap reaksi enzim dari mikroorganisme rumen.

Kenaikan KcBK seiring dengan KcBO (Tabel 6 dan Tabel 7), hal ini sesuai dengan pendapat Muhtarudin dan Liman (2006) yang menyatakan bahwa peningkatan KcBK bahan pakan akan diikuti dengan peningkatan $\mathrm{KcBO}$ ransum. $\mathrm{BO}$ merupakan komponen terbesar dari BK pakan (Munasik, 2007). $\mathrm{KcBO}$ yang cenderung naik rataannya bisa disebabkan karena lignin yang turun karena adanya perlakuan penambahan urea dan kalsium hidroksida sehingga bakteri dapat memanfaatkan selulose dan hemiselulosa yang diubah menjadi energi.

Ikatan lignin merupakan penghambat kecernaan dinding sel tanaman. Semakin banyak lignin terdapat dalam dinding sel maka koefisien cerna hijauan tersebut semakin rendah. Namun dengan perlakuan alkali terhadap pengolahan limbah maka akan terjadi pemutusan ikatan-ikatan tersebut. Alkali dapat melonggarkan ikatan lignoselulosa dan lignohemiselulosa, sehingga lignoselulosa membengkak dan bagian selulosa kristal berkurang, sehingga memudahkan penetrasi enzim yang dihasilkan mikrobia rumen lebih sempurna, akibatnya akan meningkatkan $\mathrm{KcBK}, \mathrm{KcBO}$, dan dinding sel.

Hubungan antara kandungan PK dan $\mathrm{KcBk}$ terlihat positif karena terjadi kenaikan yang seiring yang mengindikasikan kenaikan protein meningkatkan kecernaan bahan kering, hal ini sesuai dengan pernyataan Njidda dan Ikhimioya (2010).

Peningkatan BO yang tercerna disebabkan kerja enzim selulase yang dihasilkan mikrobia akan menyebabkan membukanya ikatan-ikatan serat kasar dan memungkinkan enzim selain selulolitik lebih mudah mendigesti substratnya (Yusiati et al., 1995). Kecernaan bagas tebu setelah amoniasi mengalami kenaikan jika dibandingkan bagas tebu yang tidak mendapatkan perlakuan amoniasi 
dikarenakan alkali yang ditambahkan pada bagas tebu dapat membuka ikatan lignoselulosa maupun lignohemiselulosa sehingga bakteri yang ada dapat memanfaatkan bagas tebu tersebut dengan melepaskan enzim-enzimnya sesuai pendapat (Beukes dan Brett, 2010) yang menyatakan penambahan alkali berfungsi merenggangkan ikatan lignoselulosa dan lignohemiselulosa sehingga selulosa dapat dimanfaatkan oleh mikrobia karena lebih mudah dalam penetrasi enzim.

\section{Kesimpulan}

Berdasarkan hasil penelitian dapat disimpulkan bahwa perlakuan dengan level urea dan $\mathrm{Ca}(\mathrm{OH})_{2}$ masing-masing mempengaruhi komposisi kimia dan kecernaan bagas tebu. Penambahan urea dengan level 3\% dan kalsium hidroksida 6\% pada bagas tebu menunjukkan hasil optimal dilihat dari kandungan PK.

\section{Daftar Pustaka}

Afzalani. 2004. Pengaruh amoniasi menggunakan larutan urea terhadap karakteristik degradasi bagas sebagai pakan ternak ruminansia. J. Ilmu-Ilmu Peternakan 7(1): 36-45.

Alborés, A., M.J. Pianzzola, M. Soubes, and M.P. Cerdeiras. 2006. Biodegradation of agroindustrial wastes by Pleurotus spp for its use as ruminant feed. J. Biotechnol. 9(3): 215220.

AOAC. 2005. Official Methods of Analysis. Association of Analytical Chemists, $18^{\text {th }}$ ed. Arlington Virginia, USA.

Asosiasi Gula Indonesia. 2010. Produksi Tanaman Tebu di Indonesia Tahun 2010. Jakarta. Indonesia.

Beukes, N. and I.P. Brett. 2010. Effect of lime pretreatment on the synergistic hydrolysis of sugarcane bagasse by hemicellulases. Bioresour. Technol. 101(12): 1-7.

Buxton, R.D. and D.D. Redfearn. 1997. Plant limitations to digestion and utilization. J. Nutr. 127: 814-818.

Clayton, E.H., P.C. Wynn, R.J. Mailer, and J.W. Piltz. 2010. Total lipid and fatty acid profiles in fresh and ensiled forages grow in Australia. Proc. Aust. Soc. Anim. Prod. 28: 58.

Fadel, E.A.M.A., J. Sekine, M. Hishinuma, and K. Hamana. 2003. Effects of ammonia, urea plus calcium hydroxide and animal urine treatments on chemical composition and in sacco degradability of rice straw. Asian-Aust. J. Anim. Sci. 16 (3): 368-373.
Firdos, T., A.D. Khan, and F.H. Shah. 1989. Improvement in the digestibility of bagasse pith by chemical treatment. J. Islamic Academy Sci. 2(2): 89-92.

Gillies. 1978. Animal Feed from Waste Material. Noves Data Coorporation. Park Ridge. New Jersey.

Hadad, S.G., R.J. Grant, and T.J. Klopfenstein. 1994. Digestibility of alkali - treated wheat straw measured in vitro or in vivo using Holstein heifers. J. Anim. Sci. 72: 32583265 .

Khan, M.F., A. Ah, and Z.O. Muller. 1995. Nutritional evaluation of sugarcane bagasse based rations treated with urea and cattle manure. Anim. Feed Sci. Technol. (38): 135141.

Lim, H.K. 1967. Penissetum purpureum. Malay. Agri. J. 46(1): 63.

Muhtarudin dan Liman. 2006. Penentuan tingkat penggunaan mineral organik untuk memperbaiki bioproses rumen pada kambing secara in vitro. Jurnal Ilmu-ilmu Pertanian Indonesia 8: 132-140.

Munasik. 2007. Pengaruh umur pemotongan terhadap kualitas hijauan sorgum manis (Shorghum bicolor L. Moench) varietas RGV. Prosiding Seminar Nasional : 248-253.

Njidda, A.A. and I. Ikhimioya. 2010. Corelation between composition and in vitro dry matter digestibility of leaves of semi-arid browses of North-Eastern Nigeria. American-Eurasian J.Agric \& Environ. Sci. 9(2): 169-175.

Pina, D.S., L.O. Tedeschia, S.C. Valadares Filho, J.A.G. Azevedo, E. Detmann, and R. Anderson. 2009. Influence of calcium oxide level and time of exposure to sugarcane on in vitro and in situ digestive kinetics. Anim. Feed Sci. Technol. 153: 101-112.

Salminen, S., A. von Wright, and A. Ouwehand. 2004. Lactic Acid Bacteria Microbiological and Fuctional Aspect. $3^{\text {rd }}$ ed. Marcel Dekker, Inc. New York.

Steel, R.G.D. dan J.H. Torrie. 1993. Prinsip dan Prosedur Statistika suatu Pendekatan Biometrik. Edisi kedua. Terjemahan oleh B. Sumantri. PT. Gramedia Pustaka Utama. Jakarta. Hal. 237- 267.

Suksombat, W. 2004. Comparison of different alkali treatment of bagasse and rice straw. Asian-Aust. J. Anim. Sci. 17(10): 1430-1433.

Tilley, J.M.A. and R.A. Terry. 1963. A two stage technique for the in vitro digestion of forage crops. J. British Grassland Soc. 18(2): 104.

Trach, N. X., M. Mo, and C.X. Dan. 2001. Effect of treatment of rice straw with lime and/or urea on its chemical composition, in vitro gas 
production and in-sacco degradation characteristics. J. livestock research for rural development 13(4): 1-14.

Utomo, R. 2010. Modifikasi metode penetapan kecernaan in vitro bahan kering atau bahan organik. Buletin sintesis 15(1): 1-11.

Van Soest, P.J. 1994. Nutritional Ecology of the Ruminant. Second edition. Cornell University Press. Ithaca.

Yusiati, L.M., Z. Bachrudin, Kustono, and Rachmadi. 1995. Chemical evaluation of lignocellulolytic microbes, yeast and lactobacilli addition to rice straw at silage preservation. Bulletin of Anim. Sci. Special Edition. Fac. of Anim. Sci. UGM. Yogyakarta. Pp: 267-270.

Zade, M.S., N. Dabiri, J. Fayazi, and M. Boujar Pour. 2009. Determination of level of steam pressure hydrolyzed pith bagasse in feeding of crossbred beef. J. Biol. Sci. 4(7): 773-776. 